\title{
Effect of folic acid and tetrahydrofolate on tissue arsenic level in rat
}

\author{
Md. Faizur Rahman and Mir Misbahuddin \\ Department of Pharmacology, Faculty of Basic Sciences, Bangabandhu Sheikh Mujib Medical University, Shahbag, \\ Dhaka 1000, Bangladesh.
}

\begin{tabular}{|c|c|}
\hline Article Info & \\
\hline Received: & 12 November 2009 \\
\hline Accepted: & 13 April 2010 \\
\hline Available Online: & 22 May 2010 \\
\hline DOI: $10.3329 /$ bjp. & $55 i 1.4909$ \\
\hline $\begin{array}{l}\text { Cite this article: } \\
\text { Effect of folic ac } \\
\text { folate on tissue a } \\
\text { Rahman MF, Misk } \\
\text { ladesh J Pharmaco }\end{array}$ & $\begin{array}{l}\text { id and tetrahydro- } \\
\text { rsenic level in rat. } \\
\text { bahuddin M. Bang- } \\
\text { 1. 2010; 5: 25-29. }\end{array}$ \\
\hline
\end{tabular}

\begin{abstract}
Quest is still going on for a cheap, effective, and easily available remedy for chronic arsenic toxicity. This study was designed to investigate the effects of folic acid and tetrahydrofolate in lowering the arsenic burden in tissues. Rats received arsenic at $700 \mathrm{pg} /$ day by gavage for 28 days except the control group. Arsenic accumulation was significantly lowered $(p<0.05)$, in liver, kidney, heart, lung and skin in both the folic acid and tetrahydrofolate-treated groups compared to arsenic only treated group. The oxidative stress induced by arsenic treatment was reduced as evident by the reduction in rise of malondialdehyde level in both groups. But folic acid was found to be more efficacious compared to tetrahydrofolate.
\end{abstract}

\section{Introduction}

High concentration arsenic consumption through drinking water and food is a major public health problem in Bangladesh (Tondel et al., 1999; Misbahuddin, 2003). At present more than 25,000 are suffering from arsenicinduced skin manifestations and it is predicted that $0.2-$ 0.3 million people will die due to arsenic-induced cancer (Meharg and Rahman, 2003). Recent report shows that people consuming arsenic without skin manifestation may shows systemic manifestation (Majumdar et al., 2009).

But any specific treatment for chronic arsenic toxicity is yet to be found. Researchers have suggested the use of corn (Chowdhury et al., 2009), spirulina (Misbahuddin et al., 2006), spinach (Umar, 2007), a-lipoic acid, $\beta$-carotene, vitamin A, ascorbic acid (Saha, 2006), a-tocopherol and zinc (Kamaluddin and Misbahuddin, 2006).

Arsenic-induced chronic toxicity varies from person to person. Significant ameliorative efficacy of cystine, methionine, ascorbic acid and thiamine is reported in experimental arsenic toxicity in rats when given simultaneously as compared to post exposure treatment (Nandi et al., 2005). One-carbon metabolism, the bioche- mical pathway responsible for methylation of arsenic, is a folate-dependent pathway. Folate deficiency is not uncommon largely because naturally occurring folate is highly susceptible to oxidative degradation, as it happens during cooking process. Prevalence of folate deficiency and hyperhomocysteniemia is not uncommon in rural Bangladesh (Gamble et al., 2005)

Current study was undertaken to investigate the beneficial effects of folate on experimentally induced arsenic toxicity in rat.

\section{Materials and Methods \\ Chemicals and reagents}

Arsenic trioxide $\left(\mathrm{As}_{2} \mathrm{Cb}\right)$, silver diethyldithiocarbamate (SDDC), hexamethylenetetramine, zinc fillings and other reagents for arsenic estimation were purchased from E. Merck (Germany). Thiobarbituric acid (TBA) and reduced glutathione (GSH) were purchased from Sigma Aldrich Cheme (Gmbh, Germany). Folic acid was collected from Beximco Pharma (Bangladesh).

Twenty four male Long Evan's rats weighing 160-200 g, aged between 4 to 5 months and maintained on a pellet 
Bangladesh J Pharmacol 2010; 5: 25-29

diet in the animal house were used. Room was well ventilated, temperature was kept towards normal and 12/12 hours light/dark cycle was maintained.

\section{Preparation of tetrahydrofolate from folic acid}

Folic acid $1.7 \mathrm{~g}$ with a water content of about $8 \%$ was suspended in a solution of $1.8 \mathrm{mg} \mathrm{Pb}(\mathrm{NO} 3) 2$ in $20 \mathrm{~mL}$ de-ionized water. The $\mathrm{pH}$ of the mixture was adjusted to 7.5 by the drop wise addition of $20 \% \mathrm{NaOH}$ under vigorous stirring at room temperature. A clear solution was obtained and was cooled to $10^{\circ} \mathrm{C}$. A solution of 0.05 $\mathrm{g} \mathrm{NaBHi}$ in $25 \mathrm{~mL}$ de-ionized water was added drop wise over $20 \mathrm{~min}$ under stirring at this temperature. During this addition the $\mathrm{pH}$-value of the mixture was kept between 8.5 and 8.8 by means of the drop wise addition of $20 \%$ aqueous citric acid. After completion of $\mathrm{NaBH} 4$ addition, temperature was allowed to increase to $23^{\circ} \mathrm{C}$ under stirring, and it was stirred at this temperature for further 2 hours. Then this solution was cooled to $10^{\circ} \mathrm{C}$ under vigorous stirring and drop wise $18 \% \mathrm{HCl}$ was added until the mixture had a $\mathrm{pH}$ value of 3.6. During this acidification the tetrahydrofolate precipitated. The precipitated tetrahydrofolate was isolated by means of filtration, washed once with degased and de-ionized water and once with $90 \%$ ethanol. The obtained solid was dried under reduced pressure. There were obtained $1.6 \mathrm{~g}$ tetrahydrofolate.

\section{Study design}

The rats were randomly divided into 4 groups to assess the effect folic acid and tetrahydrofolate on arsenic level. Each rat received normal diet and water ad libitum. One group received normal diet and water ad libitum for 28 days and considered as control. Arsenic group received $700 \mathrm{pg}$ (Umar, 2007) of arsenic $(0.7 \mathrm{~mL}$ of solution containing $1 \mathrm{mg} / \mathrm{mL}$ of arsenic) everyday by stomach tube for 28 days. Arsenic plus folic acid group received $700 \mathrm{pg}$ of arsenic for 21 days and in addition 1 $\mathrm{mL}$ of folic acid solution ( $200 \mathrm{pg} / \mathrm{mL}$ ) from day 22 to day 28 by stomach tube. Arsenic plus tetrahydrofolate group received $700 \mathrm{pg}$ of arsenic for 21 days and from day 22 to day 28 received $1 \mathrm{~mL}$ of tetrahydrofolate solution $(200 \mathrm{pg} / \mathrm{mL})$ by stomach tube.

The rats of all groups were sacrificed on day 29 . Sacrifice procedure was performed under chloroform anesthesia. The abdomen of each rat was opened by midline incision and extended to open the thorax. Then liver, kidneys, lungs, heart were dissected out and a portion of skin from the abdominal area was cut out. These organs were packed in separate polyethylene packets which were accurately labeled and preserved in a deep freezer until the period of analysis.

\section{Estimation of tissue arsenic level}

Total amount of tissue arsenic in all organs were measured by quantitative colorimetric method for total arsenic estimation using SDDC method. In this method inorganic arsenic is reduced to arsine $\left(\mathrm{AsH}_{3}\right)$ by zinc in a strong acid solution in an arsine generator. Arsine is then passed through a scrubber containing cotton wool moistened with lead acetate into an absorber tube containing SDDC dissolved in chloroform. Arsine reacts with the silver salt, forming a soluble red color complex whose absorbance is measured by a spectrophotometer (UV- VIS Spectrophotometer-1201, Shimadzu, Japan) at $525 \mathrm{~nm}$. There were two steps: Acid digestion and arsine generation.

\section{Estimation of MDA level}

Lipid peroxidation was estimated using the thiobarbituric acid method to determine the level of MDA, which serves as an index of lipid peroxidation. One milliliter of tissue homogenate was taken in a test tube to which $4.5 \mathrm{~mL}$ of $5.5 \%$ TCA was added. The mixture was vortexed (Vortex mixer-2000, Digisystem Laboratory, Taiwan) and centrifuged at 1,725 x g for $10 \mathrm{~min}$. The supernatant was poured into another test tube. $1 \mathrm{~mL}$ of $0.7 \%$ TBA was added to it. The mixture was kept in a boiling water bath $\left(100^{\circ} \mathrm{C}\right)$ for $10 \mathrm{~min}$. Then, it was turned into a pink color solution. The mixture was then cooled immediately and the absorbance was taken at $532 \mathrm{~nm}$ by spectrophotometer. Lipid peroxidation was calculated using molar extinction coefficient for MDA of $1.56 \times 10^{5} \mathrm{~mol} / \mathrm{L}$.

\section{Statistical analysis}

Statistical analysis was done by Statistical Package for Social Science (SPSS), version 11. The quantitative variables were expressed as mean \pm SE. ANOVA (multiple comparisons) was done to compare means of different treatment groups with that of negative control and positive control groups.

\section{Results}

Arsenic concentration in various tissues of rats treated with arsenic at $700 \mathrm{pg}$ by gavage for 28 days with or without folic acid or tetrahydrofolate is shown in Table I. Significantly higher levels of arsenic were seen in all tissues of rats treated with only arsenic as compared to control group $(\mathrm{p}<0.001)$. Highest accumulation (16.3 $\mathrm{pg} / \mathrm{g}$ ) was observed in liver. Arsenic burden was significantly reduced in both groups treated in the last seven days with folic acid and tetrahydrofolate $(p<0.05)$. Higher efficacy was noted in group treated with folic acid. However the reduction of arsenic burden was not sufficient enough for mean values to be comparable with respective control values.

Highest inhibition (64.9\%) took place in liver of folic acid treated group (Table II). Reduction in all tissues was noted to be higher in folic acid treated group as compared to tetrahydrofolate treated group. 
Table I

Arsenic concentration ( $\mu \mathrm{g} / \mathrm{g}$ of tissue) in different tissues of rats given different treatments

\begin{tabular}{|c|c|c|c|c|c|}
\hline \multicolumn{2}{|c|}{ Treatment $(n=6)$} & \multicolumn{2}{|c|}{ Liver } & \multicolumn{2}{|c|}{ Kidney } \\
\hline \multicolumn{2}{|l|}{ Control } & \multicolumn{2}{|c|}{$2.7 \pm 0.4$} & \multicolumn{2}{|c|}{$2.4 \pm 0.5$} \\
\hline \multicolumn{2}{|l|}{ Arsenic } & \multicolumn{2}{|c|}{$16.3 \pm 2.0^{a}$} & \multicolumn{2}{|c|}{$14.5 \pm 1.2^{\mathrm{a}}$} \\
\hline \multicolumn{2}{|l|}{ Folic acid } & \multicolumn{2}{|c|}{$7.5 \pm 0.7 \mathrm{~b}$} & \multicolumn{2}{|c|}{$7.1 \pm 0.6^{b}$} \\
\hline \multicolumn{2}{|c|}{ Tetrahydrofolate } & \multicolumn{2}{|c|}{$8.9 \pm 0.8^{b}$} & \multicolumn{2}{|c|}{$8.0 \pm 0.7 \mathrm{~b}$} \\
\hline \multicolumn{6}{|c|}{ ap $<0.001$ compared to control group; $b p<0.05$ compared with group ex } \\
\hline \multicolumn{6}{|c|}{ Table II } \\
\hline \multicolumn{6}{|c|}{$\begin{array}{l}\text { Percent reduction of arsenic level in different tis- } \\
\text { sues of rats given different treatments }\end{array}$} \\
\hline \multirow[t]{2}{*}{ Groups } & \multicolumn{5}{|c|}{ \% inhibition } \\
\hline & Liver & Kidney & Skin & Lung & Heart \\
\hline Folic acid & 64.9 & 61.3 & 53.4 & 44.3 & 52.0 \\
\hline $\begin{array}{l}\text { Tetrahydro- } \\
\text { folate }\end{array}$ & 54.5 & 53.6 & 31.3 & 29.7 & 41.4 \\
\hline
\end{tabular}

Figure 1 shows MDA concentration, an end product indicative of the degree of lipid peroxidation in liver, kidney, heart, lung and skin from the experimental rats. The level of MDA in all these tissues from arsenic only treated group was significantly $(p<0.001)$ higher than respective control (not treated with arsenic) values. Highest concentration of MDA was observed in liver (mean- $16.6 \mathrm{nmoL} / \mathrm{g}$ of tissue) and the lowest in skin. The rise was about 2-fold compared to control group. Treatment with folic acid and tetrahydrofolate could prevent the rise in MDA level in all tissues analyzed, but folic acid was found to be slightly more efficacious than tetrahydrofolate. MDA level in skin and lung of tetrahydrofolate treated group was not significantly lowered as compared to arsenic only treated group.

\section{Discussion}

The overall objective of this study was to observe how folate supplementation influences the arsenic level in different tissues in an animal model. Concentration of arsenic was risen by many folds in different organs of rats following the administration of arsenic compared to control group. It is evident from this study that coadministration of folic acid and tetrahydrofolate with arsenic reduced the arsenic burden significantly. In rats treated with only arsenic, the highest accumulation of arsenic was detected in liver followed by kidney, liver, lung and skin. Different biokinetic pattern of its distribution in various tissues (Lindgren et al., 1982) could be responsible for these differences.

Inorganic arsenic such as AsIII and AsV are metabolized to MMA and DMA, and then rapidly cleared from tissues through urine. However, this biomethylation

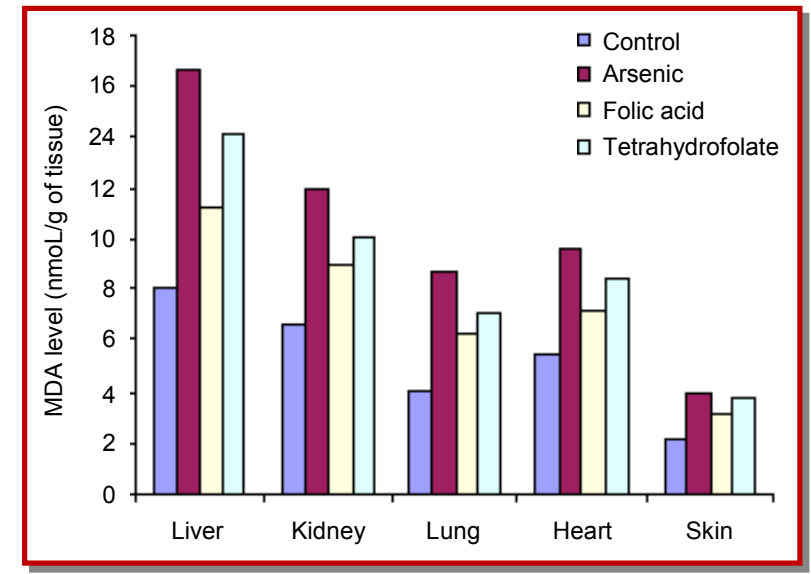

Figure 1: MDA levels in different tissues from rats given different treatments

process can easily become saturated and leads to the excess inorganic arsenic being deposited in the skin, hair and nails, where it binds tightly to keratin (Baldwin and Marshall, 1999). Individual nutritional status may be an important factor in this regard. A cross sectional study in the US compared the dietary intake of 30 nutrients to urinary arsenic metabolites and found that subjects in lowest quartile for protein intake have significantly higher \% MMA and a significantly lower \%DMA than did highest quartile for protein intake (Steinmaus et al., 2005). No association was found between dietary folate intake and arsenic methylation, likely because the study was conducted after the United States mandated folic acid fortification. A case control study in the West Bengal of India, found a modest increase in the risk of arsenic-induced skin lesions in persons who fell in the lowest quartiles for dietary intake of protein, folate, calcium and fiber (Mitra et al., 2004).

Another cross sectional study in Bangladesh found plasma folate concentrations were positively correlated with \%DMA and negatively correlated with \%MMA and \% InAs (Gamble et al., 2005). In humans and most common laboratory animals, inorganic arsenic is extensively methylated and the metabolites are excreted primarily in the urine (Gomez-Caminero et al., 2001). Though the folate status of the study animals could not be ascertained, results indicate that similar reactions 
might have occurred in the rats and folate treatment reduced arsenic burden in tissues by enhancing its methylation.

Arsenic toxicity is mediated via the generation of reactive oxygen species (Ramos et al., 1995), which in turn lead to the development of carcinogenesis and other cytotoxic effects (Wang and Huang, 1994).

Low folate intake results in elevated plasma homocysteine concentration in healthy men (Jacob et al., 1994). In vitro studies have shown that homocysteine exerts its toxicity on endothelial cells by increasing $\mathrm{H} 2 \mathrm{O} 2$ production, affecting anti-oxidant defense systems (Blundell et al., 1996).

In animals, the liver contains the most body folate storage and is susceptible to folate depletion (Clifford et al., 1990). One carbon metabolism is disturbed by folate deficiency (Balaghi and Wagner, 1995). In folate depleted animals strong negative correlation was found between plasma homocysteine and hepatic folate concentration. Elevated plasma homocysteine concentrations in folate depleted rats were strongly and significantly correlated with increased lipid peroxidation in either the absence or presence of additional oxidative stress (Huang et al., 2001). Possible mechanism for reduction in MDA concentration among the folate treated groups in this study was probably due to the reduction in homocysteine concentration.

Both Folic acid and the tetrahydrofolate has been found to be effective in lowering tissue arsenic burden in this study though folic acid was found to be slightly more effective. This could be due to the difference in their rate of absorption. Body readily absorbs up to 90 percent of folic acid (supplement form). However, further studies with folic acid and tetrahydrofolate with different doses are needed to be carried out to ascertain the therapeutic benefit in chronic arsenic poisoning.

\section{References}

Balaghi M, Wagner C. Folate deficiency inhibits pancreatic amylase secretion in rats. Am J Clin Nutr. 1995; 61: 90-96.

Baldwin DR, Marshall WJ. Heavy metal poisoning and its laboratory investigation. Ann Clin Biochem. 1999; 36: 267300 .

Blundell G, Jones BG, Rose FA, Tudball N. Homocysteine mediated endothelial cell toxicity and its amelioration. Atherosclerosis 1996; 122: 163-72.

Chowdhury NJA, Misbahuddin M, Rahman MS. Corn extracts lower tissue arsenic level in rat. Bangladesh Med Res Counc Bull. 2009; 35: 21-25.

Clifford AJ, Heid MK, Muller HG, Bills ND. Tissue distribution and prediction of total body folate of rats. J Nutr. 1990; 120: 1633-39.
Gamble MV, Liu X, Ahsan H, Pilsner JR, Ilievski V, Slavkovich V, Parvez F, Chen Y, Levy D, Factor-Litvak P, Graziano JH. Folate and arsenic metabolism: A double-blind, placebocontrolled folic acid-supplementation trial in Bangladesh. Am J Clin Nutr. 2006; 84: 1093-101.

Gamble MV, Liu X, Ahsan H, Pilsner JR, Ilievski V, Slavkovich V, Parvez F, Chen Y, Levy D, Factor-Litvak P, Graziano JH. Folate, homocysteine, and arsenic metabolism in arsenicexposed individuals in Bangladesh. Environ Health Perspect. 2005; 113: 1683-88.

Gomez-Caminero A, Howe P, Hughes M, Kenyon E, Lewis DR, Moore M. Properties and analytical procedures: Arsenic and arsenic compound. Environmental health criteria 224. International programme on chemical safety. Geneva, World Health Organization, 2001, pp 9-27.

Huang RF, Hsu YC, Lin HL, Yang FL. Folate depletion and elevated plasma homocysteine promote oxidative stress in rat livers. J Nutr. 2001; 131: 33-38. PMid:11208935

Jacob RA, Wu MM, Henning SM, Swendseid ME. Homocysteine increases as folate decreases in plasma of healthy men during short-term dietary folate and methyl group restriction. J Nutr. 1994; 124: 1072-80. PMid:8027858

Kamaluddin M, Misbahuddin M. Zinc supplement on tissue arsenic concentration in rats. Bang Med Res Coun Bull. 2006; 32: 87-91.

Lindgren A, Vahter M, Dencker L. Autoradiographic studies on the distribution of arsenic in mice and hamsters administered 74As-arsenite or -arsenate. Acta Pharmacol Toxicol. 1982; 51: 253-65. PMid:7136731

Majumdar KK, Guha Mazumder DN, Ghose N, Ghose A, Lahiri S. Systemic manifestations in chronic arsenic toxicity in absence of skin lesions in West Bengal. Indian J Med Res. 2009; 129: 75-82.

Meharg AA, Rahman MM. Arsenic contamination of Bangladesh paddy field soils: Implications for rice contribution to arsenic consumption. Environ Sci Technol. 2003; 37: 229-34.

Misbahuddin M. Consumption of arsenic through cooked rice. Lancet. 2003; 361: 435-36.

Misbahuddin M, Islam AZ, Khandker S, Ifthaker-Al-Mahmud, Islam N, Anjumanara. Efficacy of spirulina extract plus zinc in patients of chronic arsenic poisoning: A randomized placebo-controlled study. Clin Toxicol (Phila). 2006; 44: 13541.

Mitra SR, Mazumdar DN, Basu A, Block G, Haque R, Samanta S, Ghosh N, Smith MM, von Ehrenstein OS, Smith AH. Nutritional factors and susceptibility to arsenic-caused skin lesions in West Bengal, India. Environ Health Perspect. 2004; 112: 1104-09. PMid:15238285

Nandi D, Patra RC, Swarup D. Effect of cysteine, methionine, ascorbic acid and thiamine on arsenic-induced oxidative stress and biochemical alterations in rats. Toxicology 2005; 211: 26-35.

Ramos O, Carrizales L, Yanez L, Mejia J, Batres L, Ortiz D, Diaz-Barriga F. Arsenic increased lipid peroxidation in rat tissues by a mechanism independent of glutathione levels. 
Environ Health Perspect. 1995; 103: 85-88.

Saha B. Effect of ascorbic acid on reduced glutathione level in arsenic-loaded isolated liver tissues of rat. Bangladesh J Pharmacol. 2006; 1: 68-71.

Steinmaus C, Carrigan K, Kalman D, Atallah R, Yuan Y, Smith AH. Dietary intake and arsenic methylation in a U.S. population. Environ Health Perspect. 2005; 113: 1153-59. PMid:16140620

Tabassum NE. Effect of alpha-lipoic acid on the removal of arsenic from arsenic-loaded isolated liver tissues of rat.
Bangladesh J Pharmacol. 2006; 1: 27-32.

Tondel M, Rahman M, Magnuson A, Chowdhury IA, Faruquee MH, Ahmad SA. The relationship of arsenic levels in drinking water and the prevalence rate of skin lesions in Bangladesh. Environ Health Perspect. 1999; 107: 727-29.

Umar BU. Effect of hexane extract of spinach in the removal of arsenic from rat. Bangladesh J Pharmacol. 2007; 2: 27-34.

Wang TS, Huang H. Active oxygen species are involved in the induction of micronuclei by arsenite in XRS- 5 cells. Mutagenesis 1994; 9: 253-57. 